\title{
Constructing Legal Politics of Primary Education with Pancasila Character
}

\author{
Fadhil Purnama Adi $^{1}$, I Gusti Ayu Rahmi Handayani ${ }^{2}$, Hartiwiningsih ${ }^{3}$ \\ ${ }^{1.2 .3}$ Universitas Sebelas Maret \\ Surakarta, Indonesia \\ adifadhil@student.uns.ac.id
}

\begin{abstract}
The objective of research is to construct legal politics of primary education in preparing the superior students with Pancasila character in order to answer the ever changing challenge of time. This study was a doctrinal legal research using deductive logic and interpretative (hermeneutic) analysis. Philosophically, the construction of nation's character is a basic need in the nation process because only the nation with strong character and self-identity will exist. Referring to the "law as a tool of social engineering", the construction of legal politics of primary education with Pancasila character conducted should be revolutionary, i.e. changing consciously and fundamentally the strong effect of incompatible schools of thought like liberalism, communism, and radicalism into legal politics of primary education constituting the reflection of the $\mathbf{4 5}$ points of Pancasila.
\end{abstract}

Keywords- Pancasila, Politic, Indonesia.

\section{INTRODUCTION}

Legal politics of education has been described clearly in Republic of Indonesia's 1945 Constitution (UUD 1945) and National Education System. Legal Politics in this context is defined as the Direction of Policy taken by government in planning, enacting, and/or enforcing the law to construct a legal system in the attempt of realizing state's objective, government's objective, and/or presidential vision; the process and the product (output) of which are determined by political interaction occurring within.[1] Thus, legal politics of national education compulsorily refers to the state's objectives as contained in the constitution, written clearly in the fourth paragraph of 1945 Constitution's Preamble. The Republic of Indonesia state's Objectives are: "to protect all the people of Indonesia and all the independence and the land that has been struggled for, and to improve public welfare, to educate the life of the people and to participate toward the establishment of a world order based on freedom, perpetual peace and social justice.[2]

Furthermore, Article 2 of Law Number 2 of 1989 about National Education System (UU Sisdiknas) mentions that national education functions to develop nation's competency and shapes nation's dignified character and civilization in the attempt of educating the life of people, aiming to develop the students' potency in order to be faithful, healthy, knowledgeable, competent, creative, independent human obedient to God the One and Only, with noble character, and to be democratic and responsible citizens.[3]

One of Indonesians' strengths in dealing with the uncertainly changing time challenge, the founding fathers of Indonesia have bequeathed Pancasila as the nation's ideology, the supply and social capital to unite the nation.[4] But, unfortunately, the phenomenon encountered by Indonesian young generations today is that they are considered as the ones not understanding Pancasila, and even stereotyped as "micin" generation (micin is Indonesian slang of monosodium glutamate or MSG, flavoring on junk food), this term is the representation of human being serving more as "user" than as "creator". Just like "micin (flavoring)" strengthening the flavor of food, human beings, particularly the youths, only utilize and develop the existing technology.[5]

Only very few of them make innovation to develop new ideas. Ministry of National Education states that there are six problems encountered by Indonesians in the development of nation character: a) Disorientation and poor understanding on Pancasila values as the nation's philosophy and ideology, b) Limited number of Integrated Policy set in bringing the essential values of Pancasila into reality, c) the shift of ethical values in Nation and State's life, d) the fading consciousness of Nation's Cultural Values, e) the threat of Nation Disintegration, and $\mathrm{f}$ ) the weakening nation independence.[6]

During his first reign period, President Jokowi has launched Nawacita (ten ideals) policy as the promise to be brought into reality when he is elected to be a President. The $8^{\text {th }}$ Nawacita is related to primary education policy, to make nation character revolution through the policy of reforming national education curriculum by putting the civic education aspect forward, positioning proportionally educational aspects such as the teaching of nation's establishment history, patriotism and love to homeland values, spirit of state defense and noble character in Indonesian education curriculum.[7]

This study focused on legal politics of primary education because primary education level is the very important stage to inculcate the values to create such character as wanted corresponding to the objective of 
national education. Pancasila personality is a value to be grounded in the character of students at primary level, because Pancasila as the state's ideology and the source of any legal source, so that they can be the front guard to welcome a very rapid and frequently unpredictable time development in the future. The problem is that educational policy in Indonesia has had tradition of "the succession of minister will lead to the change of policy".

\section{RESEARCH METHOD}

This study was a doctrinal legal research. This research started with conducting a legal research belonging to doctrinal research. A doctrinal legal research, according to Soetandyo, is the one on the law conceptualized and developed based on doctrine adhered to by the concept creator and/or the developer. The approaches used were conceptual and historical ones. The law materials collected, particularly legal documents, were analyzed using deductive logic and interpretative (hermeneutic) methods.[8]

\section{FINDINGS AND DISCUSSION}

Legal politics, according to Padmo Wahyono, is a basic policy determining the direction, form, and content of law to be developed. Meanwhile, according to Bernard Tanya, "We call legal politics when the law is assigned to assume a society, a nation, and a state's mission to bring the vision intended by the society, nation, and state into reality.[9] Here there is a kind of common ideology that is imperative in nature, i.e. to achieve the collective objective. So in legal politics perspective, the law may not be utilized haphazardly beyond the ideal collective objective of a society, nation, and state. Furthermore, according to Adi Sulistiyono, it is the direction taken by Government in planning, enacting, and/or enforcing the law to construct a legal system in the attempt of realizing state and government's objectives, and/or president's vision, the process and the product (output) of which is determined by political interaction occurring within it.[10]

Considering the definition above, legal politics is defined as a public policy in the form of legislation, particularly in primary education scope governing Pancasila character education. Meanwhile Lickona explained that character education can be conducted through knowing, acting, and habit stages. Education and character, according to Guralnik, viewed from etymological aspect, the word character in English and "charassein" in Greek means to engrave until a pattern is created, and it can also defined as "individual's moral behavior pattern".[11]

Therefore, to educate the children in order to have character, the "engraving" process is required, i.e. appropriate caretaking and education. The values of character education material, according to Ministry of National Education, includes aspects of religiosity, honesty, tolerance, discipline, hard work, creativity, independency, democracy, curiosity, nationality spirit, love-to-homeland, appreciating achievement, friendliness/communicativeness, love and peace, reading habit, environment care, social care, and responsibility.[12]

Legal politics of primary education related to character development has been reflected on Law Number 20/2003 about National Education System (Sisdiknas), Law Number 5 of 2017 about Cultural Promotion, Minister of National Education's Regulation (Permendiknas) Number 22/2006 about Standard Content, Permendiknas Number 23/2006 about SKL, Perpres (President's Regulation) Number 87 of 2017 about Character Education Reinforcement, Inpres (Presidential Instruction) Number $1 / 2010$ about the Acceleration of National Development Priority Implementation in 2010, stating/requiring/instructing the development of students' character through education at school. Article 3 of National Education System Law (Act) mentions that national education functions to develop ability and to create the nation's character and dignified civilization in the attempt of educating the life of people. National education aims to develop the students' potency in order to be faithful human obedient to God the One and Only, having noble character, healthy, knowledgeable, competent, creative, independent, and to be democratic and responsible citizens.[13]

The objectives of character education, according to Ministry of National Education, are 1) to develop inner/conscience/affective potency of students as humans and citizens with nation's cultural values and character; 2) to develop students' habit and commendable behavior and in line with universal values and religious nation's culture and tradition; 3) to inculcate leadership spirit and responsibility among the students as the nation's next generation; 4) to develop students' ability of being independent and creative human with nationality insight; and 5) to develop the school life environment as a safe, honest, creative and friendly learning environment, with high nationalism and full power. Character education functions (1) to build multicultural national life; (2) to build smart nation civilization with high culture in order to contribute to the development of mankind life; to develop basic potency in order to have kind heart, positive thinking, good behavior, and good role modeling; (3) to build the citizens' love and peace, creativity, independency, and ability of living adjacently to other nations in harmony.[14]

Character Education is so important that the President's legal politics is directed to the Character Education Reinforcement (PPK), Republic of Indonesia's President Regulation (Perpres) Number 87 of 2017 about Character Education Reinforcement, stipulated by President Joko Widodo on September 6, 2017. The Perpres mentions that PPK aims: a) to build and to equip Students as Indonesian golden generation of 2045 with Pancasila spirit and good character education to deal with the changing dynamic in the future; b) to develop national education platform putting character education to be the main spirit in Organizing Education for Students with 
Public Participation support performed through formal-, non-formal-, and informal-channel Education by taking Indonesian cultural diversity into account; and c) to revitalize and to strengthen educators, teaching staffs, students, society, and family environment's potency and competency in implementing PPK. Furthermore, PPK is implemented by applying Pancasila values to character education particularly involving religiosity, honesty, tolerance, discipline, hard work, creativity, independency, democracy, curiosity, nationality spirit, love-to-homeland, achievement appreciation, communicativeness, love and peace, reading habit, environment care, social care, and responsibility values.[15]

The next stage of policy implementation is the way of implementing a policy in order to achieve the specified objective. The implementation of educational policy is the actualization of educational policy that has been ratified as an attempt of formulating the educational policy enacted in practice. Educational policy is developed as a guideline in acting, directing the activity in organization or school with society and government in achieving the objective. Ahmad Rusdiana suggested three pillars of main activity in the implementation of educational policy: interpretation, organization, and application. Interpretation is an activity of translating the meaning of program into the acceptable and implementable arrangement.[16]

The organization is to arrange or to order units or containers used to implement the program. Application is a consequence manifested into the fulfillment of equipment or cost needed. Implementation, according to Kunandar, is a process of applying idea, concept, policy, and innovation to an action, thereby giving impact, including the change of knowledge, skill, and value and attitude. Meanwhile, according to Novan Ardi Wiyani, implementation is an activity of realizing the plan into real action in the attempt of achieving the objective effectively and efficiently, thereby will have value.[17]

The characteristic of Primary School's students, according to psychosocial development theory suggested by Erik Ericson, includes the following stages. Stage $1(0$ - 1 year): trust versus mistrust, stage 2 (2-3 years): autonomy versus shame, stage 3 (4-5 years): initiate versus guilt, stage 4 (6-11 year) industry versus inferiority, stage 5 (12-18 year) identity versus confusion, stage 6 (19-35 year) intimacy versus isolation, stage 7 (36-65 year) generativity versus stagnation, and stage 8 (over 65 year) integrity versus despair. Generally, primary school students are 6 to 12 years old; thus, viewed from Erik Ericson's psychosocial development theory, they belong to industry stage. This stage is characterized by children's wish to get others' recognition by producing something defined as industry. As such, in this stage children need guiding, direction, example, and role model from older people.[18]

Children also have cognitive development, just like cognitive development theory suggested by Jean Piaget including (1) sensory motor stage $(0-22$ months $)$, children's intellectual behavior can be seen from the motor activity as sensory stimulus reaction. Children's movement is concrete in nature and based on pure reflex movement, (2) pre-operational stage (24 months-7 years), children has had internal activity, had language mastery, symbolic game, and imitation in the form of mental imagination. In this period, children think egocentrically and have not been able to take others' perspective, (3) concrete operational stage (7-11 years); in this stage egocentric thinking pattern has reduced and children begin to be able to pay attention to other dimension instantaneously. In this phase, children's thinking pattern is concrete in which they can differentiate two different objects if the objects are present. Children can understand something when it is real, observable, touchable, and tangible, (4) formal operational stage (11 years and more), in this phase the children's mindset is not bond but separated spatially and temporally. In this phase, children can think abstractly or related to the intangible phenomenon.[6]

Assessment measures not only the students' achievement in knowledge and skill but also their character development. Assessment technique and instrument selected and implemented not only measure the development of students' personality but should also be applied to the development of students' personality all at once. To measure the successful level of character education implementation in educational unit, a variety of assessment programs is implemented through comparing prior condition and the achievement at certain time. The assessment of achievement is conducted in the following stages: 1) developing indicators of values specified or approved, 2) developing a variety of assessment instruments, 3) recording the achievement of indicator, 4) conducting analysis and evaluation, and 5) taking followup action. Lavonen \& Meisalo suggested the need for the implementation of creative problem solving learning model, putting the students onto real situation, because the problem posed is ill-defined, complex, and meaningful one, with creative solution from the students.

\section{IV.CONCLUSION}

Philosophically, the construction of nation's character is a basic need in the nation process because only the nation with strong character and self-identity will exist. Ideologically, character development is an attempt of embodying Pancasila ideology into living within nation and state. Referring to the "law as a tool of social engineering" theory, the construction of legal politics of primary education with Pancasila character conducted should be revolutionary, i.e. changing consciously and fundamentally the strong effect of incompatible schools of thought like liberalism, communism, and radicalism into legal politics of primary education constituting the reflection of the 45 points of Pancasila as mandated in the Tap MPR No.1 Tahun 2003. It should be reflected on Law Number 20/2003 about National Education System (Sisdiknas), Law Number 5 of 2017 about Culture Promotion, Permendiknas Number 22/2006 about 
Standard Content for Primary and Secondary Education Units, Permendiknas Number 23/2006 about Graduate Competency Standard (SKL), Perpres (President's Regulation) Number 87 of 2017 about Character Education Reinforcement, Inpres (Presidential Instruction) Number 1 of 2010 about the Acceleration of National Development Priority Implementation in 2010, stating/requiring/instructing the development of students' character through education at school.

\section{REFERENCES}

[1] A. A. Herman and M. J. Hayat, "Management of High Secondary Education After Regional Government Law," J. Hum. Rights, Cult. Leg. Syst., vol. 1, no. 2, pp. 395-396, 2021.

[2] Syahlan, "Effective and Efficient Synchronization in Harmonization of Regulations Indonesia," J. Hum. Rights, Cult. Leg. Syst., vol. 1, no. 1, pp. 54-70, 2021.

[3] I. G. A. K. R. Handayani, A. Sulistiyono, T. Leonard, A. Gunardi, and F. U. Najicha, "Environmental management strategy in mining activities in forest area accordance with the based justice in Indonesia," $J$. Leg. Ethical Regul. Issues, vol. 21, no. 2, 2018.

[4] Z. N. Rosidah, "Coherence of the Rules of Sharia Against Pancasila," Bestuur, vol. 8, no. 1, p. 40, 2020.

[5] D. E. Wibowo, "Ewuh Pakewuh Cultural Reconstruction to Equal Consumer Protection," J. Best., vol. 8, no. 1, pp. 1-8, 2020.

[6] R. Res, "Implementation of Parate Executie Object of Liability Juridical Overview of Mortgage," J. Hum. Rights, Cult. Leg. Syst., vol. 1, no. 1, pp. 42-53, 2021.

[7] A. Ma, "Legal Aspects of Environment in Indonesia : an Efforts to Prevent Environmental Damage and Pollution," J. Hum. Rights, Cult. Leg. Syst., vol. 1, no. 1, pp. 18-30, 2021.

[8] L. Karjoko, Z. N. Rosidah, and I. G. A. K. R. Handayani, "Refleksi Paradigma Ilmu Pengetahuan Bagi Pembangunan Hukum Pengadaan Tanah Lego," Bestuur, vol. 7, no. 2, pp. 1-14, 2019.

[9] L. Karjoko, D. W. Winarno, Z. N. Rosidah, and I. G. A. K. R. Handayani, "Spatial planning dysfunction in East Kalimantan to support green economy," Int. J. Innov. Creat. Chang., vol. 11, no. 8, pp. 259-269, 2020.

[10] M. H. Ahmadi, I. G. A. K. R. Handayani, and L. Karjoko, "Problems in law of mortgage right law number 4 Tahun 1997," Int. J. Adv. Sci. Technol., vol. 28, no. 20, pp. 321-324, 2019.

[11] L. C. Lintang, Adriano Martufi, and J.W. Ouwerker, "The Alternative Concepts of Blasphemy Law in Indonesia: Legal Comparison with Ireland and Canada," Bestuur, vol. 8, no. 2, pp. 121-128, 2020.

[12] M. Pungky and H. Wijaya, "Legislation Impediments in Reorganising Government Bodies in Indonesia," Bestuur, vol. 9, no. 1, pp. 1-16, 2021.

[13] U. K. Mishra and A. Negi, "Transgender and the Right to Employment in India: Analysing the
Trajectories of Discrimination," Bestuur, vol. 9, no. 1, pp. 34-43, 2021.

[14] Saidah Fasihah Binti Che Yussoff and R. Nordin, "Freedom of Expression in Malaysia: Compatibility with the International Human Rights Standard Saidah," Bestuur, vol. 9, no. 1, pp. 44-59, 2021.

[15] H. J. Noor, K. Afkar, H. Glaser, and U. G. Mada, "Application of Sanctions Against State Administrative Officials Failing to Implement Administrative Court Decisions," Bestuur, vol. 9, no. 1, pp. 73-93, 2021.

[16] W. B. Putri et al., "Medicolegal Perspective on Physician-Induced Demand Issue," Bestuur, vol. 9, no. 1, pp. 106-124, 2021.

[17] I. G. A. K. R. Handayani, L. Karjoko, and A. K. Jaelani, "Model Pelaksanaan Putusan Mahkamah Konstitusi yang Eksekutabilitas Dalam Pengujian Peraturan Perundang-Undangan di Indonesia," Bestuur, vol. 7, no. 1, pp. 36-46, 2019.

[18] A. K. Jaelani, I. G. A. K. Rachmi Handayani, and L. Karjoko, "EXECUTABILITY OF THE CONSTITUTIONAL COURT DECISION REGARDING GRACE PERIOD IN THE FORMULATION OF LEGISLATION," Int. J. Adv. Sci. Technol., vol. 28, no. 15, pp. 816-823, 2019. 